\title{
Effects of Non-genetic Factors on Body Weight Traits in Rambouillet Sheep
}

\author{
Anamika ${ }^{1}$, D. Chakraborty ${ }^{2}$, R.K. Taggar ${ }^{2}$, Simran Singh $^{2}$, \\ Peer Mohd. Azhar ${ }^{3}$ and Parul Gupta ${ }^{4}$ \\ ${ }^{1}$ V.A.S., State Govt. of J\&K, India \\ ${ }^{2}$ Division of Animal Genetics \& Breeding, FVSc\&AH, SKUAST-Jammu, R.S.Pura, \\ Jammu-181102, India \\ ${ }^{3}$ Division of Animal Genetics \& Breeding, SKUAST-Kashmir, India \\ ${ }^{4}$ KVK-Rajouri, SKUAST-Jammu, India \\ *Corresponding author
}

\begin{abstract}
A B S T R A C T
Keywords

Birth weight, Body

weight Yearling

weight, Non-genetic

factors and

Rambouillet sheep

Article Info

Accepted:

12 November 2018

Available Online:

10 December 2018

Data on growth traits of 7151 animals used in present study were collected from the history sheets of Rambouillet sheep maintained at Government Sheep Breeding Farm, Zaban, Reasi, J\&K, India, over a period of 16 years (2000-2015). Body weight traits were birth weight $(\mathrm{BW})$, three month body weight $(3 \mathrm{MW})$, six-month body weight $(6 \mathrm{MW})$, nine-month body weight $(9 \mathrm{MW})$ and yearling weight $(\mathrm{YW})$. The data were classified to study the major effect of non-genetic factors like period of lambing, season of lambing, sex of lamb and type of birth. Based on these classifications, the significant effects were adjusted for performance traits. The overall least squares means were $3.17 \pm 0.04 \mathrm{~kg}$, $13.97 \pm 0.14 \mathrm{~kg}, 19.08 \pm 0.20 \mathrm{~kg}, 24.65 \pm 0.25 \mathrm{~kg}$ and $28.01 \pm 0.23 \mathrm{~kg}$, for BW, $3 \mathrm{MW}, 6 \mathrm{MW}$, $9 \mathrm{MW}$ and $\mathrm{YW}$, respectively. The effect of period of lambing and sex of lambs were significant $(\mathrm{P}<0.01)$ on all the body weight traits. The effect of season of lambing was non-significant on all traits. The effect of type of birth i.e. single and twinning was highly significant only on birth weight. Males were heavier than females for all the body weight traits. It can be concluded from the present study that non-genetic factors affecting the growth traits in Rambouillet sheep.
\end{abstract}

\section{Introduction}

Jammu \& Kashmir state of India is enriched with sheep population and ranks $5^{\text {th }}$ in total sheep population in the country with a population of 3.28 million, where as India's sheep population is 65.06 million. The percentage share of total sheep population of $\mathrm{J} \& \mathrm{~K}$ state is around $5.21 \%$. Likewise, a decrease of around $17.87 \%$ is reported from the state as well $\left(19^{\text {th }}\right.$ Livestock Census, 2012).

The traits of economic importance in sheep include growth traits which directly fetches profit to the farmers. Growth potential of the lambs is one of the most important traits in a genetic improvement programme/scheme for mutton sheep. Early growth traits are important factors influencing profitability in 
any meat producing enterprise. With the rising prices of mutton in the market, fast growing and heavier lambs are in great demand. The economics of sheep production is greatly affected by the growth performance as heavier lambs with high growth rate would fetch relatively more economic returns in lesser time span compared to weaker lambs (Narula et al., 2009). These growth traits are influenced by several genetic and non-genetic factors vis. sex of lamb, type of birth, climate and seasonal variation during different years. Among these factors, seasonal and climatic variations from year to year affect the production of the whole flock, whereas sex, type of birth and age affect the performance of an individual. It is, therefore, imperative to estimate the extent of all such factors so that the genetic variation among animals can be used to design breeding plans for further improvement. Therefore, the present investigation was undertaken to study the effects of different non-genetic factors on growth traits in Rambouillet sheep.

\section{Materials and Methods}

Body weight records of 7151 animals were collected from history sheets of Rambouillet sheep maintained at Government Sheep Breeding and Research Farm, Reasi, Jammu, India over a period of 16 years (2000-2015). The Government Sheep Breeding and Research Farm, Reasi. Body weight traits included in the study were birth weight (BW), three month body weight (3MW), six-month body weight (6MW), nine-month body weight (9MW) and twelve-month body weight or yearling weight (YW). All the traits under present study were normalized. The effects of non-genetic factors such as periods, seasons, birth type and sex on various normalized traits were analyzed by least-squares analysis using the technique developed by Harvey (1990) as follows:
$\mathrm{Y}_{\mathrm{ijklm}}=\mu+\mathrm{P}_{\mathrm{i}}+\mathrm{S}_{\mathrm{j}}+\mathrm{C}_{\mathrm{k}}+\mathrm{B}_{1}+\mathrm{e}_{\mathrm{ijklm}}$

Where,

$\mathrm{Y}_{\mathrm{ijklm}}=\mathrm{m}^{\text {th }}$ record of individual lambed in $\mathrm{i}^{\text {th }}$ period, $\mathrm{j}^{\text {th }}$ season of $\mathrm{k}^{\text {th }}$ sex and of $1^{\text {th }}$ birth type

$\mu=$ Overall population mean

$\mathrm{P}_{\mathrm{i}}=$ Fixed effect of $\mathrm{i}^{\text {th }}$ period of lambing

$S_{j}=$ Fixed effect of $j^{\text {th }}$ season of lambing

$\mathrm{C}_{\mathrm{k}}=$ Fixed effect of $\mathrm{k}^{\text {th }}$ sex

$\mathrm{B}_{1}=$ Fixed effect of $1^{\text {th }}$ birth type

$\mathrm{e}_{\mathrm{ijklm}}=$ Random error associated with each observation and assume to be normally and independently distributed with mean zero and variance $\left(0, \sigma_{\mathrm{e}}^{2}\right)$

For significant effects, the differences between pairs of levels of effects were tested by Duncan's multiple range test as modified by Kramer (1957).

\section{Results and Discussion}

The overall least squares means were $3.17 \pm 0.04 \mathrm{~kg}, 13.97 \pm 0.14 \mathrm{~kg}, 19.08 \pm 0.20 \mathrm{~kg}$, $24.65 \pm 0.25 \mathrm{~kg}$ and $28.01 \pm 0.23 \mathrm{~kg}$, for BW, $3 \mathrm{MW}, 6 \mathrm{MW}, 9 \mathrm{MW}$ and $\mathrm{YW}$, respectively (Table 2).

\section{Effect of period of lambing}

Significant effect $(\mathrm{P}<0.01)$ of period of lambing was reported for all the traits under study (Table 1). There was an increasing trend of birth weight over the period of lambing. The highest BW was observed during P4 (2012-2015). There was no definite trend over the period of lambing for other body weight traits. The lowest WW, 9MW and YW were observed during $\mathrm{P} 4$ which is not desirable one. It may be due to the fact that during last period there was flood or natural calamities which led to washed out of green pastures and other feed resources that subsequently resulted into lower growth rate and simultaneously low weaning weight. 
Momoh et al., (2013) in Balami, Uda sheep reported significant effect of period of lambing on BWT, $3 \mathrm{MW}$ and $6 \mathrm{MW}$ where as non-significant effect on 9MW and YW. Ganesan et al., (2013) also reported significant effect of period of lambing on BWT, 3MW, $6 \mathrm{MW}, 9 \mathrm{MW}$ and YW in Madras Red sheep. Khan et al., (2013) reported significant effect of period on BWT in Rambouillet sheep. Das et al., (2014) reported non-significant effect of year of lambing on $\mathrm{BW}$ in Kashmir Merino sheep. Significant effect of period/year of lambing was reported in 6MW and $\mathrm{YW}$, whereas, non-significant effect on BWT in Dorper crossbred sheep (Zaffer et al., 2015a; Zaffer et al., 2015b; Chakraborty et al., 2015). Gupta et al., (2015) reported significant effect on BWT in Rambouillet crossbred sheep. Reddy et al., (2017) reported significant effect on BW, 6MW, 9MW and YW, whereas, nonsignificant effect on $3 \mathrm{MW}$ in Nellore brown sheep.

\section{Effect of season of lambing}

Season of lambing had non-significant effect on all the traits under study (Table 1). However, lambs born during winter season were superior for $\mathrm{BW}, 3 \mathrm{MW}, 6 \mathrm{MW}$ and $\mathrm{YW}$, whereas, lambs born during other seasons were superior for $9 \mathrm{MW}$. This may be due to the reason that ewes got lustrous fodder or green grasses at highland pastures which increased the body weight of lambs born during other seasons or may be due to the fact that lambs born during winter seasons lost more body energy for preventing the cold whereas lambs born during other seasons needed less energy to prevent from environmental temperature (cold) and conserved more energy.

Momoh et al., (2013) reported significant effect of season of lambing on BWT, $3 \mathrm{MW}$ 9BW and YW in Balami, Uda sheep, whereas, non-significant effect on 6MW. Khan et al.,
(2013) reported non-significant effect of season on BWT in Rambouillet sheep. Ganesan et al., (2013) reported non-significant effect on BWT and 9BW, whereas, significant effect on 3MW, 6MW and YW in Madras Red sheep. Das et al., (2014) reported nonsignificant effect of season of lambing on BW in Kashmir Merino sheep. Gupta et al., (2015) reported non-significant effect on BWT in crossbred sheep. Similar to present findings non-significant effect of season on BWT, 6 MW and YW in Dorper crossbred sheep were also reported (Zaffer et al., 2015a; Zaffer et al., 2015b; Chakraborty et al., 2015). Reddy et al., (2017) reported significant effect on BW, $6 \mathrm{MW}, 9 \mathrm{MW}$ and YW and non-significant effect on 3MW in Nellore brown sheep.

\section{Effect of sex}

Sex was found to have highly significant effect on all the traits under present investigation (Table 1). This establishes the role of sex hormones in male and female growth and also the physiological status of male and female lambs during growth. Differences in sexual chromosomes, probably in the position of genes related to growth, physiological characteristics and differences in endocrinal system lead to difference in animal growth (Rashidi et al., 2008). Higher growth in prenatal stage is under the influence of male hormones with anabolic effect (Hafez, 1962).

Significant effects of sex on BWT, 3MW, $6 \mathrm{MW}, 9 \mathrm{MW}$ and $\mathrm{YW}$ were reported in Balami, Uda sheep (Momoh et al., 2013), Madras Red sheep (Ganesan et al., 2013) and Nellore brown sheep (Reddy et al., 2017). On contrary to present investigation, significant effects of sex on BW and non-significant effect on 6MW and YW were reported on Dorper crossbred sheep (Zaffer et al., 2015a; Zaffer et al., 2015b; Chakraborty et al., 2015). 
Table.1 Analysis of variance for various body weight traits in Rambouillet sheep

\begin{tabular}{|l|l|l|l|l|l|}
\hline Source of variation & \multicolumn{5}{|c|}{ Mean sum of squares } \\
\cline { 2 - 4 } & $\mathbf{B W}$ & $\mathbf{3 M W}$ & $\mathbf{6 M W}$ & $\mathbf{9 M W}$ & YW \\
\hline Period of lambing & $474.96^{* *}$ & $545.08^{* *}$ & $717.27^{* *}$ & $3041.29^{* *}$ & $2946.74 * *$ \\
& $(3)$ & $(3)$ & $(3)$ & $(3)$ & $(3)$ \\
\hline Season of lambing & 0.02 & 1.71 & 16.83 & 0.553 & 23.19 \\
& $(1)$ & $(1)$ & $(1)$ & $(1)$ & $(1)$ \\
\hline Sex of lambs & $32.06^{* *}$ & $69.33^{* *}$ & $493.78^{* *}$ & $1837.81^{* *}$ & $3436.83 * *$ \\
& $(1)$ & $(1)$ & $(1)$ & $(1)$ & $(1)$ \\
\hline Type of birth & $20.39^{* *}$ & 7.56 & 44.42 & 116.68 & 72.35 \\
& $(1)$ & $(1)$ & $(1)$ & $(1)$ & $(1)$ \\
\hline Remainder & 0.57 & 5.89 & 10.88 & 11.62 & 13.68 \\
& $(7144)$ & $(6409)$ & $(5858)$ & $(4982)$ & $(4523)$ \\
\hline
\end{tabular}

Figures in parenthesis are degrees of freedom

${ }^{*} \mathrm{P}<0.05 \quad{ }^{* *} \mathrm{P}<0.01$

Table.2 Least-squares means and their standard errors of birth weight (BW), three month body weight (3MW), six month weight (6MW), nine month body weight (9MW) and yearling weight (YW) in Rambouillet sheep

\begin{tabular}{|c|c|c|c|c|c|}
\hline Particulars & BW (kg) & 3MW (kg) & 6MW (kg) & 9MW (kg) & YW (kg) \\
\hline Overall mean & $\begin{array}{l}3.17 \pm 0.04 \\
(7151)\end{array}$ & $\begin{array}{l}13.97 \pm 0.14 \\
(6416)\end{array}$ & $\begin{array}{l}19.08 \pm 0.20 \\
(5865)\end{array}$ & $\begin{array}{l}24.65 \pm 0.25 \\
(4989)\end{array}$ & $\begin{array}{l}28.01 \pm 0.23 \\
(4530)\end{array}$ \\
\hline \multicolumn{6}{|l|}{ Period of lambing } \\
\hline P1 (2000-2003) & $\begin{array}{l}2.64^{\mathrm{a}} \pm 0.04 \\
(1562)\end{array}$ & $\begin{array}{l}13.01^{\mathrm{a}} \pm 0.15 \\
(1230)\end{array}$ & $\begin{array}{l}18.35^{a} \pm 0.22 \\
(1132)\end{array}$ & $\begin{array}{l}25.35^{\mathrm{b}} \pm 0.34 \\
(515)\end{array}$ & $\begin{array}{l}27.68^{b} \pm 0.33 \\
(332)\end{array}$ \\
\hline P2 (2004-2007) & $\begin{array}{l}2.87^{b} \pm 0.04 \\
(1560)\end{array}$ & $\begin{array}{l}14.37^{b} \pm 0.15 \\
(1523)\end{array}$ & $\begin{array}{l}18.58^{a} \pm 0.21 \\
(1448)\end{array}$ & $\begin{array}{l}25.49^{b} \pm 0.25 \\
(1424)\end{array}$ & $\begin{array}{l}29.48^{\mathrm{c}} \pm 0.27 \\
(1380)\end{array}$ \\
\hline P3 (2008-2011) & $\begin{array}{l}3.39^{c} \pm 0.04 \\
(1772)\end{array}$ & $\begin{array}{l}14.33^{b} \pm 0.15 \\
(1651)\end{array}$ & $\begin{array}{l}19.84^{b} \pm 0.21 \\
(1461)\end{array}$ & $\begin{array}{l}25.19^{b} \pm 0.26 \\
(1424)\end{array}$ & $\begin{array}{l}28.73^{c} \pm 0.28 \\
(1278)\end{array}$ \\
\hline P4 (2012-2015) & $\begin{array}{l}3.77^{\mathrm{d}} \pm 0.04 \\
(2257)\end{array}$ & $\begin{array}{l}14.19^{b} \pm 0.15 \\
(2012)\end{array}$ & $\begin{array}{l}19.54^{b} \pm 0.22 \\
(1824)\end{array}$ & $\begin{array}{l}22.55^{\mathrm{a}} \pm 0.26 \\
(1626)\end{array}$ & $\begin{array}{l}26.15^{\mathrm{a}} \pm 0.28 \\
(1540)\end{array}$ \\
\hline \multicolumn{6}{|l|}{ Season of lambing } \\
\hline Winter (Dec-Feb) & $\begin{array}{l}3.17 \pm 0.28 \\
(7011)\end{array}$ & $\begin{array}{l}14.03 \pm 0.09 \\
(6289)\end{array}$ & $\begin{array}{l}19.28 \pm 0.13 \\
(5756)\end{array}$ & $\begin{array}{l}24.60 \pm 0.17 \\
(4908)\end{array}$ & $\begin{array}{l}28.29 \pm 0.18 \\
(4452)\end{array}$ \\
\hline Others & $\begin{array}{l}3.16 \pm 0.06 \\
(140)\end{array}$ & $\begin{array}{l}13.92 \pm 0.23 \\
(127)\end{array}$ & $\begin{array}{l}18.88 \pm 0.34 \\
(109)\end{array}$ & $\begin{array}{l}24.69 \pm 0.41 \\
(81)\end{array}$ & $\begin{array}{l}27.73 \pm 0.45 \\
(78)\end{array}$ \\
\hline \multicolumn{6}{|l|}{ Sex of lambs } \\
\hline Male & $\begin{array}{l}3.24^{\mathrm{b}} \pm 0.04 \\
(3574)\end{array}$ & $\begin{array}{l}14.08^{\mathrm{b}} \pm 0.14 \\
(3228)\end{array}$ & $\begin{array}{l}19.37^{b} \pm 0.21 \\
(2967)\end{array}$ & $\begin{array}{l}25.26^{\mathrm{b}} \pm 0.25 \\
(2478)\end{array}$ & $\begin{array}{l}28.91^{\mathrm{b}} \pm 0.27 \\
(2231)\end{array}$ \\
\hline Female & $\begin{array}{l}3.10^{\mathrm{a}} \pm 0.04 \\
(3577)\end{array}$ & $\begin{array}{l}13.87^{\mathrm{a}} \pm 0.14 \\
(3188)\end{array}$ & $\begin{array}{l}18.79^{\mathrm{a}} \pm 0.21 \\
(2898)\end{array}$ & $\begin{array}{l}24.04^{\mathrm{a}} \pm 0.26 \\
(2511)\end{array}$ & $\begin{array}{l}27.12^{\mathrm{a}} \pm 0.28 \\
(2299)\end{array}$ \\
\hline \multicolumn{6}{|l|}{ Type of birth } \\
\hline Single & $\begin{array}{l}3.33^{\mathrm{b}} \pm 0.03 \\
(6951)\end{array}$ & $\begin{array}{l}14.11 \pm 0.11 \\
(6243)\end{array}$ & $\begin{array}{l}19.34 \pm 0.16 \\
(5703)\end{array}$ & $\begin{array}{l}25.16 \pm 0.20 \\
(4865)\end{array}$ & $\begin{array}{l}28.41 \pm 0.22 \\
(4413)\end{array}$ \\
\hline Twin & $\begin{array}{l}3.01^{\mathrm{a}} \pm 0.06 \\
(200)\end{array}$ & $\begin{array}{l}13.87 \pm 0.21 \\
(173)\end{array}$ & $\begin{array}{l}18.81 \pm 0.30 \\
(162)\end{array}$ & $\begin{array}{l}24.13 \pm 0.37 \\
(124)\end{array}$ & $\begin{array}{l}27.61 \pm 0.41 \\
(117)\end{array}$ \\
\hline
\end{tabular}

Figures in parentheses are number of observations.

Means with different superscripts differ significantly among themselves 


\section{Effect of type of birth}

Type of birth carried highly significant effect only on birth weight under present study (Table 1). All other traits were no-significant for type of birth. This reflects that during twinning, there is intra-uterine competition between the foetus for space in uterus which is required for proper growth of foetus and also for placental nutrition, whereas, in single-born lambs, there is ample intra-uterine space for fetal growth and also the placental nutrition. The twining born lambs might have demonstrated compensatory growth after weaning. Momoh et al., (2013) reported significant effect of type of birth on BWT, $3 \mathrm{MW}$ and 6MW, whereas, non-significant effect on 9MW and YW in Balami, Uda sheep. Sudan (2018) reported significant effect of type of birth on BW, 9MW and YW in Rambouillet sheep.

Therefore, it can be concluded that different non-genetic factors significantly affecting the body weight traits of Rambouillet sheep.

\section{Acknowledgement}

Authors are thankful to Director, Sheep Husbandry, Jammu, and the In-charge and staff of Government Sheep Breeding and Research Farm, Reasi, Jammu for providing facilities and help for the present study.

\section{References}

$19^{\text {th }}$ Livestock census. 2012. Department of Animal Husbandry, Dairying \& Fisheries, Govt. of India, New Delhi.

Chakraborty D., Zaffer V., Anamika, Rameez M., Kumar D and Taggar R.K. 2015 Genetic studies on growth traits and growth rates in Dorper Crossbred sheep. Asian Resonance 4(2): 29-32.

Das A K, Chakraborty D, Kumar N, Gupta P, Khan N and Bukhari S. 2014. Effects of non-genetic factors on performance traits of Kashmir Merino sheep. Indian Journal of Animal Research 48(2):106108.

Ganesan, R., Dhanavanthan, P., Balasubramanyam, D. and Kumarasamy, P. 2013. Estimates of genetic parameters of growth traits in Madras Red sheep. IOSR Journal of Agriculture and Veterinary Sciences 3(5):69-73.

Gupta P, Chakraborty D, Das A K, Kumar N and Khan N. 2015. Genetic studies on growth and wool production traits in Crossbred sheep of India. Indian Journal of Animal Sciences 85(3):258261.

Hafez, Z. Z. 1962. Reproduction in Farm Animals. ( $2^{\text {nd }}$ Edition). Lea and Febizer, Philadelphia.

Harvey W R. 1990. User guide for LSMLMW and MIXMDL package mixed model least squares and maximum likelihood computer programme. PC-2 version Mimeograph Columbia, Ohio, USA.

Khan N N, Kumar N, Das A K, Chakraborty D and Gupta P. 2013. Birth and weaning weights in Rambouillet crossbred sheep. Indian Veterinary Journal 90(5):36-37.

Kramer C.R. 1957. Extension of multiple range tests to group correlated means. Biometrics, 13:13-18.

Momoh, O. M., Rotimi, E.A. and Dim, N. I. 2013. Breed effects and non-genetic factors affecting growth performance of sheep in a semi-arid region of Nigeria. J. Appl. Bio Sci. 67:5302-5307.

Narula, H.K., Yadav, S.B.S., Sharma, P.R. and Mehrotra, V. 2009. Genetic evaluation of Magra sheep of Rajasthan. Indian J. Small Ruminants, 12:91-94.

Rashidi, A., Mokhtari, M. S., Safi, Jahansahi, A., Mohd. Abadi, M. R. 2008. Genetic parameter estimates of pre-weaning growth traits in Kermani Sheep. Small 
Ruminant Research, 74: 165-171.

Reddy D, Sreenivas D, Gnanaprakash M, and Harikrishna C. 2017. Genetic analysis of growth performance of Nellore Brown sheep. International Journal of Science, Environmental and Technology 6(1): 774-778.

Sudan, A. 2018. Genetic Studies and Trends on Performance Traits in Rambouillet Sheep. MVSc Thesis submitted to Shere-Kashmir University of Agricultural Sciences and Technology of Jammu,
Jammu \& Kashmir, India.

Zaffer V, Taggar R K and Chakraborty D. 2015a. Non-genetic factors affecting growth and production traits in Dorper crossbred sheep. Journal of Animal Research 5(2):227-230.

Zaffer V, Taggar R K and Chakraborty D. 2015b. Genetic studies on growth and wool production traits in Dorper $\mathrm{x}$ Rambouillet crossbred sheep. Animal Science Reporter 9 (4): 131-137.

\section{How to cite this article:}

Anamika, D. Chakraborty, R.K. Taggar, Simran Singh, Peer Mohd. Azhar and Parul Gupta. 2018. Effects of Non-genetic Factors on Body Weight Traits in Rambouillet Sheep. Int.J.Curr.Microbiol.App.Sci. 7(12): 1408-1413. doi: https://doi.org/10.20546/ijcmas.2018.712.168 